\title{
HERO CONCEPT IN THE LIGHT OF HOMER'S ILIAD AND THE DEATH OF SARPEDON, LYCIAN WARRIOR
}

\author{
Aslı SARAÇOĞLU
}

\begin{abstract}
Özet
Hero kavramı, antik çağlardan günümüze kadar, çok farklı biçimlerde ele alınmakla ve dönemlere göre değişikliğe uğramakla birlikte, geçerliliğini her zaman korumuştur. Hesiodos, Homeros, Euripides, Apollodorus, Plutarkhos gibi pek çok antik kaynak, hero ve heroin kültü ile ilgili bugün bizlere önemli bilgiler vermektedir. Herodot, Pausanias gibi kaynaklar ise heroik figürlerin din ve gelenekteki rollerine değinmekte ve onlar adına kutlanan festivalleri anlatmaktadır. Antik kaynakların ayrıntılıca bahsettiği, adları günümüze ulaşan bir çok kahraman, insanlardan farklı biçimde olağan üstü güce ve yeteneğe sahipse de, onların da insanlar gibi birer ölümlü oluşları, doğallıkla onları tanrılardan ayırmaktadır. Bu nedenle de üzerinde farklı görüşler varsa da, hero kültü genellikle tanrı tapınımından farklı görülmektedir. Ancak hero ve heroinler için ölüm kaçınılmaz olsa da, kendi adlarına ya da tanrılarla birlikte, dini festivallerle onurlandırıldıkları da bilinmektedir. Örneğin, Odysseus İthake'de kutsal bir mağarada Athena ve Hera ile birlikte, Erekhteus ise Atina'da Athena ile birlikte tapınım görmüştür. Modern araştırmacıların çoğu ise, özellikle bu kavramın kökeni ve ilk oluşumu ile ilgili araştırmalar yapmışlardır. Özellikle de bu konuyla ilgili, ilki hero kültünün M.Ö. 8. yüzyılın Homerik şiirinden geliştiği, diğeri ise hero kültünün ilk şehirlerin kuruluşuna kadar giden ölü kültüne dayandığı yönünde iki görüş ön plana çıkmaktadır. Her ne kadar köken konusu problemli görülse de, M.Ö. 8. yüzyılda Sparta'da özellikle mezar yapılarında hero kültünün izlerini taşıyan bazı verilere ulaşıılmıştır. Yine Atina'da daha geç dönemlerde özellikle, M.Ö. 5 ve 4 . yüzyıllarda farklı jenerasyonlara ait aile mezarlarının, hero kültü ile bağlantılı olduğu arkeolojik verilerle ortaya konulmuştur. Bununla birlikte hero kültünün kökeninin aslında çok daha eskilere gittiği, Prehistorik dönemde ve Bronz çağının ölü gömme geleneklerinde bu kültün izlerini taşıyan verilerin olduğunu savunanlar da bulunmaktadır. Dolayısıyla da en güzel örnekleri Mykenai, Lefkandi, Eleusis, Erythrai ve Lakonia gibi kentlerde görülen hero kültü, ölü gömme gelenekleri ve ata kültü ile bağlantılı düşünülmektedir.
\end{abstract}

Homeros'un destanında, Troya savaşında Likyalıları, Akhalılara karşı yüreklendirmesi ayrıntılı olarak anlatılan Sarpedon ise Hektor gibi en büyük Anadolu kahramanlarından biridir. Soy ağacı konusunda farklı görüşler varsa da, Homeros'un anlattığı, Troya savaşında Likyalıların başında cesurca döğüşeni, Bellerophontes'in kızı Laodameia'nın tanrı Zeus'la birleşmesinden doğandır. Yine antik kaynaklarda Sarpedon'un kült merkezinin önemli Likya kentlerinden biri olan Ksanthos olabileceği konusunda işaretler bulunmaktadır. Savaşta Patroklos'un mızrağı ile öldürülmüş ve cesedi oğlunun yazgısını değiştiremeyen babası Zeus tarafından Apollon'a verilen direktifle, gece tanrıçanın çocukları ikiz tanrılar Hypnos (Uyku) ve Thanatos (Ölüm) tarafından Likya'ya taşınmıştır. Bir tanrı oğlu olmasına rağmen, yazgısı değişmeyen Sarpedon'un dramı, antik kaynaklardan başka, özellikle seramikler üzerinde betimlenmiştir. Bu betimlemelerin en ünlüsü ise Euphronios tarafından M.Ö. 6. yüzyıl sonlarında boyanan kraterdir ve üzerinde işlenen sahne, antik kaynakların bize anlattı̆̆ı ölüm episodunu desteklemektedir.

From ancient times to the present, the phenomenon of hero, the meaning of which changes in every period, has been commonly studied and variously defined. Hero, generally a famous person, is worshipped after his death as quasi-divine 
in the Greek religion. For example, Heracles, son of Zeus and Alcmene, is a very popular hero throughout the Greek world. Most scholars have attempted to explain the distinction between heroes and gods. Heroes are clearly different from other men, and yet distinguished from gods. Heroes and heroines might be actual great men and women, real or imaginary ancestors, or "faded" gods and goddesses. While heroes and heroines, who hold a special place in ancient Greek religion, differ from gods and goddesses. Greek religious ideology also seems to demand a sharp distinction between hero and god with heroine and goddess ${ }^{1}$. Heroes are not generally accepted as gods, and are not immortal, but they possess some supernatural powers. Heroes are considered less than gods but greater than humans. Unlike the immortals, they are born, live and die. They sometimes attain the degree of immortality, such as Heracles, and take part in the status of the great gods, winning entrance between the Olympian gods ${ }^{2}$. That is to say, "if you think he's a god, you shouldn't mourn him, if you think he died, you shouldn't worship him". Consequently, the cult of heroes differs from the worship of gods.

Great heroes and heroines tend to exhibit certain excellent qualities and powers. The Greeks refer to a person's particular excellence as his or her arete, which has also been translated as "virtue": the word is actually more akin to "being the best you can be" or "reaching your highest human potential ${ }^{3}$. Ancient sources mention those

\footnotetext{
${ }^{1}$ According to Lyons, heroines differ from male heroes in several crucial ways, among which is the ability to cross the boundaries between the mortal and immortal see. Nock 1944, 141 ff; Lyons 1997, 6, footnote 9 .

${ }^{2}$ Hom. Od. 11, 601-4.

${ }^{3}$ In the Homeric poems, in addition, Arete is the most valuable and associated with bravery and loyalty. Homer applies the term to the main female
}

who fight bravely for their country. For example, Homer's Iliad recounts tales of the Lycians and Lycian heroes, the most famous of whom was Sarpedon, who fought on the side of the Trojans in defence of Troy ${ }^{4}$.

Many pages have been written concerning the hero and heroine cult in the Greek religion. In particular, the works of ancient writers like Euripides, Plutarchos and Apollodorus are important documentary sources in this regard. Ancient sources document in detail the intertwined varieties of heroes and heroines: divinely descended or favored, local, epic, eponymous, warriors, kings, founders of cities, and prophets ${ }^{5}$. For example, Pausanias, the writer of the Description of Greece, has cited heroic figures and their roles in religious tradition and practice. The cult of the heroes appears in literature for the first time in Hesiod's Works, important information, is especially provided in his Theogony. At the same time, the largest Archaic source, related to heroines, is certainly the Hesiodic Catalogue of Women. In addition, Homer has described powerful generations of men, honored heroes and the importance of their tombs in his poems. There are many examples and, numerous heroic figures have derived from Iliad and Odyssey ${ }^{6}$. Homer treats his heroes as noble and fighting men, but many Homeric heroes such as Hector, son of Priam and Hecuba, and the commander of the Trojan armies, with Achilles, one of the

figures such as Penelope, known by her royalty, the wife of the Greek hero, Odysseus. Therefore, in the Homeric poems, Arete is of the most significant value and involves of the abilities and potentialities available to humans.

${ }^{4}$ Hack 1929, 57 ff; Hadzisteliou 1973, 129 ff.

${ }^{5}$ Antonaccio 1995, 1.

${ }^{6}$ Homer's Iliad and Odyssey are the center of the ancient Greek culture in many respects, and he is the chief authority for early Greek hero cult and religious belief (Coldstream 1976, 8 ff). 
heroes of the siege of Troy, later became objects of worship. Homer focuses especially on Achilles and Hector and their wrath in the Iliad.

The Greek hero cult has also been extensively discussed by both archaeologists and philologists. There are differing views with respect to the origin of hero cults, and this has been a subject of focus for most researchers. Generally, there are two current hypotheses: (a) hero cult arose in the eighth century B.C. with the impression of Homeric poetry, (b) the hero cult was based on the ancestral cult dating back to the establishment of polis ${ }^{7}$. Nevertheless, the study of heroic experience and original heroic cult has some problems of evidence. Some archaeological evidences has indicated the origin of the earliest hero cult at Sparta during the eighth century. According to another group, the origins of hero cult are based on burial tradition in the Bronze Age and prehistorical period ${ }^{8}$. Ainian claims that hero cults in the Early Iron Age in Greece can be divided into three basic categories: tomb cults at prehistoric tombs, cults of heroes derived from Homeric poems and mythic cycles, and lastly cults in honor of the recently heroized dead ${ }^{9}$.

There are certainly far more fourth-century family tomb plots to be discovered in Athens and the Attic countryside. Many excavations in the Athenian and Attic countryside have confirmed this concept, and family tombs are frequently encountered through different generations ${ }^{10}$. Thus, the cult of the dead is

\footnotetext{
${ }^{7}$ Antonaccio 1994, 389.

${ }^{8}$ Mylonas 1948, $56 \mathrm{ff}$.

9 Ainian 1999, 9; The term "Iron Age" is used to cover the period from the end of the Bronze Age (ca. 1100) to the start of the Archaic period (ca. 700): Antonaccio 1995, 2, footnote 4.

${ }^{10}$ Humphreys 1980, $122 \mathrm{ff}$.
}

considered to be connected with the tombstone ${ }^{11}$. Nevertheless, it is rather difficult to distinguish hero cult from ancestral cult. Nock believes that hero cult differs little from the god cult ${ }^{12}$. It is not clear whether cults of the Homeric heroes were connected with Mycenaean tombs. For the most part, modern scholars have connected hero cult with ancestral cult, such as the Toumba at Lefkandi, Thermon, Eleusis, and Eretria ${ }^{13}$. But there is no evidence for hero cult at these sites.

Mycenaean tholos, or chamber tombs, are often referred to with respect to the cult of heroes. According to Förtsch, Mycenae has been rather frequently discussed in connection with the cult of heroes, which expanded at the age of Homeric and led to the foundation of various sites specifically designated for particular hero cults, socalled heroa ${ }^{14}$. This view was also supported by others ${ }^{15}$. Lambrinoudakis, agreeing with them, argues that the interest in Mycenaean ruins in Geometric Naxos may be derived from a "romantic affection" and an idealization of the Mycenaeans as "more or less legendary family-founders" in an age of emerging hero-cults ${ }^{16}$. However, Blegen and others before him have suspected a continuous cult of dead heroes since the Mycenaean age ${ }^{17}$. According to Antonaccio, tomb cults are connected with hero cults ${ }^{18}$. Among the special topics under discussion, hero cults in the Early Iron Age, Greece reflects the relationship between funerary ritual, the veneration of ancestors and the cult of heroes. However, there is no clear

\footnotetext{
${ }^{11}$ Johansen 1951, 69.

${ }^{12}$ Nock 1944, $141 \mathrm{ff}$.

${ }^{13}$ Ainian 1999, 9 ff.

${ }^{14}$ Förtsch 1995, 173.

${ }^{15}$ Hiller 1983, 13.

${ }^{16}$ Lambrinoudakis 1988, 245.

${ }^{17}$ Blegen 1937, 389 ff; Antonaccio 1994, 391 ff.

${ }^{18}$ Antonaccio 1994, 389 ff.
} 
evidence that cults of named Homeric heroes were ever connected with Mycenaean tombs, even though such tombs were known at the time.

Generally, hero and heroine cults are also associated with tombs and other sanctuaries such as Laconian hero reliefs. In Laconia, the well-known hero reliefs continued from the early Archaic period to the Hellenistic Age. Among the earliest of these are Laconian hero reliefs, dated from the seventh and sixth centuries, showing pairs tentatively identified as Agamemnon and Kassandra or Klytemnestra, and Helen and Menelaos ${ }^{19}$. Laconian "hero reliefs" have sepulchral monuments. For example, a late Archaic Laconian grave stele in $\mathrm{Ny}$ Carlsberg Glyptotek, artistically one of the most valuable in the whole series, ${ }^{20}$ is an early specimen. Laconian "hero reliefs" are shown enthroned, or at least seated, and more or less distinctly characterized as heroes $^{21}$, the closest parallels of Laconian works are in particular the Cycladic gravestones. Also, the shrine of Pelops and Hippodameia at Olympia is one of the early examples of the hero and heroine pairs, and a dedication to Helen is perhaps the earliest known Laconian inscription, dating from the second quarter of the seventh century ${ }^{22}$.

The heroic explanation emerged as a popular subject on grave reliefs and ceramics at Attica in the late sixth and early fifth centuries B.C. Recent researches have revealed that hero and heroine cults were widespread throughout Greece from the Archaic through the Classical periods. In the fifth century B.C, Athens became the political, economic, and cultural center of Greece. Particularly, the Attic grave reliefs and vases of the Classical periods are the

\footnotetext{
${ }^{19}$ Pipili 1987, $30 \mathrm{ff}$; Lyons 1997, 47, footnote.38.

${ }^{20}$ Johansen 1951, 85, Fig. 38.

${ }^{21}$ Johansen 1951, 135.

${ }^{22}$ Paus. 6, 20, 7; Lyons 1997, 8, footnote 7.
}

richest materials related to heroic explanation. It is therefore possible to see traces of hero cult, both at grave reliefs and on ceramics at Attica during this period. It is obvious that hero cults are closely related to heroic stelae ${ }^{23}$. Furthermore, early Greek sepulchral monuments have given us some idea of the stelae which are mentioned several times in the Homeric poems. The shape of the monuments with reliefs vary ${ }^{24}$. They are normally made of stone, and because of their excessive weight must be dragged up to the mound, though a wooden post may also be considered a memorial ${ }^{25}$.

These young aristocratic men often appear on their stelae as warriors in the Archaic period $^{26}$. Several examples have been found at Attica, the best and largest of which has been excellently preserved. When all are considered, they have similarities with respect to both composition and typing. Particularly, grave reliefs in Attica were depicted in athletic or attractive youth hero and heroine views. The heroic dead were likewise depicted as they were living and brave warriors. In places, such as Boeotia, Thesally, and South Italy, we see similar workshops $^{27}$. Their most remarkable feature is that they are often decorated with scenes, involving human figures, which provide valuable insights into ancient Greek customs, beliefs and opinions.

Because of the hero's inevitable mortality, many heroes and heroines are honored with ritual lamentation. Heroes are tied into the ritual calendar by being honored as part of the festival of a $\operatorname{god}^{28}$. Occasionally, a heroine is honored by her own festival,

\footnotetext{
${ }^{23}$ Broneer 1942, $130 \mathrm{ff}$.

24 But generally, the Homeric stelae are tall and slender see. Johansen 1951, $67 \mathrm{ff}$.

${ }^{25}$ Hom. Il. XXIII, 331; Od. XII, 13.

${ }^{26}$ Johansen 1951, 110, Figs. 43-44.

${ }^{27}$ Johansen 1951, 145.

${ }^{28}$ Paus. 2, 12, 5.
} 
termed as Herois $^{29}$. For example, Pausanias describes an annual celebration at Olympia in honor of Hippodameia ${ }^{30}$. In contrast with heroines, many ritual forms are connected with heroes, like games and oracles. In the Iliad, Homer mentions the burial and funeral games in honor of Patroclus ${ }^{31}$.

Death and burial were occasions for complicated rites among the Greeks. The custom of burial is one of the most important clues about ceremonial and social structure in ancient cultures. According to Norris, a conception of afterlife and ceremonies associated with burial were already well established by the sixth century B.C ${ }^{32}$. It is obvious that many important festivals are celebrated in the name of the dead in Athenian culture. Further commemorative rites were carried out on the ninth and thirtieth days after death ${ }^{33}$. Ancient literary sources like the Iliad and Odyssey emphasize the necessity of a proper burial ${ }^{34}$. According to the ancient Greeks, at the moment of death the psyche "spirit of the dead" left the body, and the dead was prepared for burial honored rituals.

Many heroes are worshipped aside from divinities of the Olympian gods, and local heroes should be honored according to ancestral customs ${ }^{35}$. As typical examples, Odysseus was honored in a Cave shrine at polis in Ithaca together with Hera, Athena and the Nymphs ${ }^{36}$. Erectheus, founder of

\footnotetext{
${ }^{29}$ Hild 1918, 139.

${ }^{30}$ Paus. 6, 20, 7

${ }^{31}$ Paus. $2,12,5$

${ }^{32}$ Norris 2000,18

${ }^{33}$ Humphreys 1980, 100 ff.

${ }^{34}$ Hom. Il. XXIII, $71 \mathrm{ff}$.

35 Hesiod. Works and Days, 159-72; Also see. Antonaccio 1994, 390; Ainian 1997, 11.

${ }^{36}$ Hom. Od. XIII, 345 ff; A ruined cave at the nortwest side of Polis Bay on the west coast of Ithaca was excavated under the direction of Benton in the
}

Athens, and Athena were widely worshipped together on the acropolis of Athens $^{37}$. Lastly, Amphiaraos was a hero, who became a curing hero near Oropos on the Attic-Boiotian border, look like Asklepios $^{38}$. In addition, numerous heroines were worshipped at their shrines during the Heroic Age. For example Iphigeneia was adored with Artemis at Brauron and Aigeira $^{39}$. However, we have limited knowledge about the form of hero-shrines, and particularly about heroine's shrines.

The cult of Sarpedon was mostly concentrated along the western regions of Anatolia's southern shore and it was worshipped. In particular, Sarpedon's chief cult center was at Xanthos, where he was probably buried in $\mathrm{Lycia}^{40}$. Sarpedon was probably worshipped in Xanthos and his cult may date back to the fifth century B.C. By the fifth century, a great cult complex had been built on the peak of Acropolis, called the Sarpedonia. The games of the Sarpedonia were probably held and regular sacrifices offered to Sarpedon.

Herodotus provides valuable information about the Lycians ${ }^{41}$. They came from Crete after Sarpedon and Minos fought for the throne, and Sarpedon had forced separation from there by victorious Minos. Herodotus reports that the Termilians of Lycia believed themselves to be descendants of colonies who had come to Asia Minor with Sarpedon from Crete. About 1600 B.C., the king of Knossos expelled Sarpedon from Crete, and he then moved to the Asian coast and founded Miletus.

1930s: Also see. Benton 1938/39, 60; Antonaccio 1995, 152 footnote. 21.

${ }^{37}$ Hom. Od. VII, 80 f; Also see. Ainian 1999, 12.

${ }^{38}$ Boardman 1995 a, 131; Hall 1999, 53.

${ }^{39}$ Paus. 8, 26, 5; Also see. Ainian 1999, 13 footnote 29.

${ }^{40}$ Hom. Il. V, 479 ff, 875 ff.

${ }^{41}$ Hdt 1. 173. 
According to Homer, Lycians came to Xanthos from distant in Sarpedon's leadership, who was born in Crete, and heroic Glaucus. In the Trojan War, he was an ally of the Trojans, and demonstrated himself to be courageous and fearless ${ }^{42}$. During the war, Glaucus was wounded. Sarpedon, when he was about to die, gave to Glaucus the destiny of the Lycians ${ }^{43}$. Glaucus had an important fame in the Lycian history like Sarpedon; therefore, Glaucus played an illustrious role in the Iliad. According to Homer reports:

\section{"The Lycians were led by Sarpedon with Glaucus, the heroes, \\ Far from Lycia, from whirling waters of Xanthus" $"$.}

In Greek mythology, Sarpedon referred to different people. For example, the name of Sarpedon, who is the son of Poseidon, is sometimes mentioned as the name of a giant, killed by Heracles in Thrakia.

According to Homeric legend, the Lycian prince Sarpedon was the son of Zeus and Laodameia, who was the daughter of Bellerophon $^{45}$. In the Iliad, the demi-god son of Zeus was the bravest general of the Trojan's allies. He led a force of the Lycians against the Greeks in the Trojan War and led the forefront of the attack on the Greeks ${ }^{46}$. For example, Hector and Achilles fight on a Corinthian cylix dated about 590-570 B.C. (Fig. 1) ${ }^{47}$. In addition, Sarpedon the rider and the Phoenix are observed in the same scene. Sarpedon is behind Hector and similarly Phoenix flanks

${ }^{42}$ Hom. Il, II. 876; V. 479; XII, 292; XVI. 550; XVII. 152; Ov. Metam. XIII, 255.

${ }^{43}$ Hom. Il. XVI, 490-500

${ }^{44}$ Hom. Il. II, 875.

${ }^{45}$ Hom. Il. VI, 195 ff; Apollod. 3.1.1; Diod. Sic. V, 79; Verg. Aen. X, 125.

${ }^{46}$ Apollod. 3, 1, 2; Paus. 7, 3, 7.

${ }^{47}$ LIMC 1981, VII/2, Taf. 519, Fig. 1.
Achilles. They are described as warriors and all of the figures in this scene are identified by names.

The Greek, Roman, and other early ancient writers dealt with the episode. For example, in tradition later from Homer, in the Crete legend, Sarpedon, as one of the greatest of all Lycian warriors, was the son of immortal Zeus and mortal Europa. Europa was the daughter of Agenor, and was loved by Zeus. Zeus took the form of a beautiful white bull and encountered Europa at the seashore. In Crete, Europa, the daughter of Phoenix, bore three sons to Zeus: Minos, Sarpedon and Rhadamantys. The heroes themselves, the sons of Zeus, are clearly named $^{48}$. Minos became the powerful king of Crete, he established a strong navy and an empire in the Aegean Sea, and the Minoan civilization was named after him. Rhadamanthys was a famous Cretan lawgiver. He was the ruler of Crete but, according to some, he had to flee from the island for his brother Minos. He went to Boeotia where he married Alcmene, the former wife of Amphitryon. Because of his honesty and fairness, he became one of the judges in the underworld.

Minos and Sarpedon were torn by conflict, perhaps regarding who would accede to the Cretan throne or because they both fell in love with a child called Miletus. Sarpedon finally left Crete and went to Asia Minor ${ }^{49}$. He settled down in the Miletus region in Lycia and became the king of Miletus. It was suggested that Miletus was founded by Sarpedon or by Miletus who had gone with him. According to post-Homeric legend, having been expelled from Crete by latter, and he was banished by his brother Minos and moved to Asia Minor, where he became the king of the Lycians ${ }^{50}$ and he is

\footnotetext{
${ }^{48}$ Hom. Il. XIV, 320; Hyg. Fab, 178; Also see. Lyons 1997, 78

${ }^{49}$ Apollod. 3. 1. 1; Paus. 7.3.7.

${ }^{50}$ Hdt. 1. 173.
} 
said to have lived for three generations. The chronological difficulty caused by the identification of the Cretan Sarpedon and the Lycian hero Sarpedon who joined the Trojan War has obliged the researchers to consider these two individuals as separate.

According to Diodoros, Sarpedon, the son of Europa, goes to Lycia and there has a son named Euandros ${ }^{51}$. $\mathrm{He}$ marries Deidameia, the daughter of Bellerophontes and she bears him the second Sarpedon (grandson of the 1st Sarpedon) who joins the Trojan War. This subject is narrated in detail in Homer's Iliad. Also Vergilius (70 B.C.-19 B.C.), the greatest of all the Roman poets, mentions another version of Sarpedon's death ${ }^{52}$.

Of these different mythological expressions, the most important was that of Homer. The death of Sarpedon is an important event in the XVIth part of the Iliad $^{53}$. In this ancient epic, the warrior Sarpedon dies the glorious death of a true hero on the battlefield. Homer describes how Sarpedon was killed and then carried away from the battlefield by Hypnos (Sleep) and Thanatos (Death), winged twin sons of Night. Zeus watches as his son, "dies raging". Zeus sent Apollo to move the body, which was then transported safely back to Lycia, his homeland in southwest Asia Minor, by Hypnos and Thanatos ${ }^{54}$. Although Zeus cannot save Sarpedon, he takes special care in the handling of the body and sends Hypnos and Thanatos to carry him home. Apollo, at the command of Zeus, cleansed Sarpedon's body of blood and dust and washed it in the river, covered it with ambrosia, and then gave it to

\footnotetext{
${ }^{51}$ Diod. Sic. IV, 60; V, 79.

${ }^{52}$ Verg. Aen., X, $465 \mathrm{ff}$.

${ }^{53}$ Nagy finds evidence of hero cult in the treatment of the dead warrior Sarpedon in the Iliad 16. Nagy 1983, 189 ff; Nagy 1990, 122 ff.

${ }^{54}$ Hom. Il. XVI, 453 ff.
}

Hypnos and Thanatos to carry to his native land Lycia, there to be honorably buried and receive due funeral rites ${ }^{55}$.

In the Iliad, the most important distinguishing characteristic of the gods, particularly of Zeus, is their ability to control events. But fate and prophecy also play an influential role in the Iliad. In the Greek religion, the fates, or Moira were the goddesses who controlled the destiny of everyone from the time they were born until their death. The Moira sometimes appear to have superior power to that of Zeus. For example, Zeus cares for his mortal sons, but often his power to help them is limited. Although Zeus possessed the power to save his mortal son Sarpedon from death on the battlefield, in the Iliad, his wife Hera rebuked Zeus, stating that Sarpedon is fated to die, and that not even he can prevent it. In fact, for Zeus to save his son, would invoke the hate of the other gods. His interference with fate would bring about chaos. If Sarpedon was permitted to return to his country alive, the other gods would attempt to rescue their own sons from the struggle ${ }^{56}$. Therefore, Zeus allows his son to die to avoid any potential conflict. In spite of his father's attempt to save him, Sarpedon was killed by the spear of Patroclus, an enemy warrior, wearing Achilles' $\operatorname{armor}^{57}$. Inevitably, Zeus directs Phoibos Apollon to come to the battle field, where Sarpedon lies wounded.

"Went down along the mountains of Ida, into the grim fight,

Lifting brilliant Sarpedon out from under the weapons,

Carried him far away, and washed him in a running river,

\footnotetext{
${ }^{55}$ Robertson 1988, 109 ff; .Norris 2000, 100.

${ }^{56}$ Hom. Il. XVI, 445.

${ }^{57}$ Bothmer 1981, $63 \mathrm{ff}$.
} 
And anointed him in ambrosia, put ambrosial clothing upon him,

Of Sleep and Death, who are twin brothers, these two presently

Laid him down within the rich countryside of broad Lycia",58.

Fate is unchangeable not only for Sarpedon, but also for the other heroes of the Iliad. In the case of Heracles, he must contend with the implacable enmity of his wife Hera, for example like Sarpedon ${ }^{59}$. Achilles as well knows that he is fated to die if he revenges the death of his close friend, Patroclus, who was slain by the mighty Hector. Thetis, Achilles' mother, took an active part in organizing the funerary ceremonies held to commemorate her son. Such is the fate of Eos, the dawn goddess, who has to bury her dead son Memnon, king of Ethiopia, killed by Achilles.

Description of the Trojan War and scenes of mourning were the frequent subject in the Archaic and Classical periods. Sarpedon, one of the most popular warriors in that war, was considered, a hero, and as a result was described widely in epics and especially on ceramics. Nevertheless, there are few descriptions in sculpture. The most famous is a bronze cista handle which belongs to Etruscan Art and is dated to the end of the fifth or beginning of the fourth century B.C. This group is now exhibited at the Cleveland Museum of Art (Fig. 2) ${ }^{60}$. The scene shows a deceased Sarpedon. His nude body is strong and anatomically accurate and wonderfully balanced with the body organs. Nudity had long been traditional in the Classical period for representing athletes, heroes and gods. The presentation of the human anatomy was impressive. Hypnos and Thanatos, both

\footnotetext{
${ }^{58}$ Hom. Il. XVI, 677-682 ff.

${ }^{59}$ Lyons 1997, 85.

${ }^{60}$ LIMC 1981, VII/2, Pl. 523, Fig. 15.; Fabing 1988, 244-249, No. 45.
}

bearded and wearing armor, lift the lifeless body of Sarpedon with his long hair hanging down the back.

The descriptions on the ceramics are the samples of sculptures, most of which have been collected in LIMC, a brilliant work distinguishing mythology and cults. In addition, works of Beazley are distinguished painters and groups in red and black figured pottery. The most of simples are connected with corpse of Sarpedon, killed by the spear of Patroclus, and transported by Hypnos and Thanatos to Lycia. Varying compositions have been found concerning with Sarpedon's death. For example, Sarpedon's dead body is seen under war vehicles on a Corinthian hydria, dated to the mid sixth century B.C. (Fig. $3)^{61}$. More than half of the hydria is missing, but two fragments have been preserved.

The tale of Sarpedon's death in the Iliad has been described on a cylix with red figure technique signed by Euphronios (Fig. 4) ${ }^{62}$. Hypnos and Thanatos carrying the dead body of Sarpedon, are being led by Acamas, the Trojan hero, who is also mentioned in the Iliad. Sarpedon's corpse is softer and slighter while his porters are broader and heavily muscled. Thanatos and Hypnos, like Acamas, were older and bearded as is know from Classical sculpture. All the figures are identified by names. Since Hypnos and Thanatos differ from each other in both character and image, these twin brothers are rarely depicted together ${ }^{63}$. But there is no

\footnotetext{
${ }^{61}$ LIMC 1981, VII/2, Pl. 520, Fig. 2.

${ }^{62}$ LIMC 1981, VII/2, Pl. 520, Fig. 3.

${ }^{63}$ According to the ancient sources, Hypnos moves kindly among the mortals but, his brother Thanatos has a heart of pitiless iron. According to Hesiod, Hypnos and Thanatos don't have a father. They are twin brothers. Although Homer does not mention the name of their mother, the ancient Greek poet Hesiod claims in Theogony that Hypnos and Thanatos are
} 
remarkable difference in their description on the cylix of Euphronios. Although they preferred to be apart, they are depicted together during transportation of corpses of famous heroes such as Sarpedon and Memnon. They gently lift the still-bleeding lifeless body of Sarpedon, from the field of battle to prepare a hero's funeral. While the figures closely resemble each other. Sarpedon's body is worked with more splendor than others, which are clothed, in contrast to the dead hero, who is weaponless and completely naked. Sarpedon is depicted larger than natural size as a young and strong man. Euphronios'cylix, nevertheless, is created with balanced and moving figures. The apparent naturalism and realism are achieved (Fig. 4).

The episode of Sarpedon's death has been described on Attic cylix with red figure technique from the late sixth century B.C., signed by Nikosthenes (Fig. 5) ${ }^{64}$. The other figures can be defined as goddesses Iris (on the left) and Sarpedon's mother or wife (on the right). The body of Sarpedon is distinguished in its heroic aspect and he is clearly separated from the other figures. Appearance of the bodies is quite naturalistic and carved in detail. The halfopen eyes of Sarpedon give the impression of a sensitive countenance. The hair is arranged in soft waves. His beard is long and slightly wavy. The faces of Hypnos and Thanatos portray an expression of sadness.

On the calyx-crater from the early fifth century B.C., signed by the painter Eucharides, two winged demons, Hypnos

the sons of Nyx, one of the daughters of Chaos (Hes. Theog. 574) Really, on the chest of Kypselos, two childrens' embrace of Nyx is described. Schefold 1964, Abb. 26; Clark-Coulson 1978, 65 ff; Carter $1989,355 \mathrm{ff}$.

${ }^{64}$ LIMC 1981, VII/2, P1. 521, Fig. 5; Robertson 1992, 39-ff, Fig. 21. and Thanatos, lift the body of Sarpedon off the ground (Fig. 6) ${ }^{65}$. The heads of the Sarpedon and Hypnos show similar stylistic features and their facial expressions are sweet and soft. The body of Thanatos has been broken.

Sarpedon's dead body is depicted on two neck amphoras signed by Diosphos (Figs. 7-8). On the neck amphora dated to the early fifth century B.C., presently displayed at Paris's Louvre Museum (Fig. 7) ${ }^{66}$, Hypnos and Thanatos deposit the body of Sarpedon; an eidolon, fully armed, flies down. On the second neck amphora with black figure tecnique from the early fifth century B.C., signed by Diosphos painter, now exhibited in New York Metropolitan Museum of Art. Hypnos and Thanatos are either lifting Sarpedon's dead body from the battlefield or laying it down in his homeland. On the same amphora, an eidolon flies upward (Fig. 8) ${ }^{67}$. In spite of their individualities the figures resemble each other. In both samples, the image of Sarpedon's is the most impressive scene in the picture. He is clearly designated and his presence as the focus of scene was carefully planned. The scene on the obverse of this amphora is connected with Memnon.

An Attic black figure technique lekythos, dated to 480-470 B.C., found in Eretrea, and presently exhibited in Berlin Staatliche Museum, is one of the masterpieces of this period (Fig. 9) ${ }^{68}$. A similar scene is reflected on the lekythos, attributed to the painter Athena. On this lekythos, Sarpedon is lifted by Hypnos and Thanatos from the battlefield after his death.

\footnotetext{
${ }^{65}$ LIMC 1981, VII/2, Pl. 521, Fig. 6.

${ }^{66}$ Haspels 1936, 238, 133; LIMC 1981, VII/2, Pl. 521, Fig. 7.

${ }^{67}$ Haspels 1936, 239, 137; LIMC 1981, VII/2, Pl.

521, Fig. 8.

${ }^{68}$ Boardman 1995 b, Fig. 251.
} 
On an Attic lekythos signed by the painter Haimon in 470 B.C., a bleeding Sarpedon who has lost his armor, is lifted by Hypnos and Thanatos. On the same lekythos, the god Poseidon holds a dolphin in his left hand (Fig. 10 a) and the god Hermes stands in front of the warrior (Fig. $10 \mathrm{~b})^{69}$.

On the fragments of an Attic cylix, now in the Florence Museum of Archaeology, dated to 470-450 B.C., the body of Sarpedon is removed by Hypnos and Thanatos from the battlefield or is laid down in his homeland. On this sample saved as two fragments from the outside of a cylix, only a small part of the legs and feet of a male figure can be distinguished (Fig. 11) ${ }^{70}$.

On an Apulian bell crater from the first quarter of the fourth century B.C., Sarpedon is depicted differently (Fig. 12) ${ }^{71}$. The mortal Europa, mother of Sarpedon, enthroned in a stage aedicula, and a woman, perhaps the wife of Sarpedon, sits by her side on a lower level. While Sarpedon's body is carried by Hypnos and Thanatos, a smaller figure, maybe the child of Sarpedon, kneels on the ground looking up. A male figure standing in the center of crater who can be considered a Lycian, gazes at the sky with both hands upraised, looking in confusion at Sarpedon's body. The upper portion of the body of Hypnos is missing but Thanatos is well preserved. In contrast to Thanatos, who wears a short chiton, Hypnos is nude, carrying a wrap over his right arm, he was probably described as a young man and without beard. The whole of the description and other figures depict the homecoming of Sarpedon.

\footnotetext{
${ }^{69}$ LIMC 1981, VII/2, P1. 522, Fig. 10.

${ }^{70}$ LIMC 1981, VII/2, P1. 522, Fig. 11.

${ }^{71}$ LIMC 1981, VII/2, Pl. 522, Fig. 14.
}

On the hydria dated to ca. 400-380 B.C., Hypos and Thanatos, aloft the body of Sarpedon whose name is incised on. Achilles is shown below them, fully armed, killing Penthesilea (Fig. 13) ${ }^{72}$.

From among the afore mentioned examples, the calyx-crater is the best known representation of the Sarpedon episode in the Iliad (Fig. $14 \mathrm{a})^{73}$. All the figures in this scene are identified by inscriptions and the vase also bears the name of the potter, Euxitheos, and painter, Euphronios. The early red figure vase still bears the marks of Archaic style, despite the talent of the Euphronios $^{74}$. His famous work, the socalled "Euphronius Vase", displayed today in New York Metropolitan Museum of Art, is one of the most magnificient masterpieces of the technique of this period. The scene is surrounded by sumptuous decoration, including stylized plant and flower forms. An uninterrupted band of upright palmettes encircles the entire vase on the rim. The scenes on the front and back of the vase are separated by palmettes. Their background is decorated with floral ornaments. All of these effective descriptions and ornaments were supported by the powerful composition.

\footnotetext{
72 LIMC 1981, VII/2, P1. 522, Fig. 13.

${ }^{73}$ LIMC 1981, VII/2, P1. 520, Fig. 4; Boardman 1996, Fig. 22.

${ }^{74} \mathrm{He}$ worked from ca. 520 to 470 B.C. and was renowned for his skill in depicting the human anatomy. Euphronios in his early career was interested in presenting the human body in different poses. He was one of the founders of Athenian vasepainters, referred to by present-day scholars as pioneers. At the same time, he was respected among the most greatest of his time, like Douris, Makron and Onesmios. As a painter and potter he signed numerous vases; he first signed at least ten vases as painter, but later in his career, like other painters such as Onesimos, he signed as potter. He crafted large craters, the calyx-crater in particular, as well as other shapes. Euphronios, one of the first workers in the red-figure method, was simple and skillfull in his technique: (Boardman 1996, 29 ff and 32).
} 
The calyx-crater signed by Euphronios is connected with heroic expression. The subject is certainly mythological and must have come from the Homeric epic, like the other hero legends. It is obvious that this composition was designed as a mythological group. The scene on the crater gives an extraordinary detailed treatment of the moment of his death. Upon careful inspection, Sarpedon is depicted as larger than the other figures. There is a band, made of oak poplar or pine, adorning Sarpedon's head. His eyes are closed, and his limp hand drags along the ground. Although Homer portrays Sarpedon as a commander, he is described as a young man by Euphronios. The anatomical appearance of Sarpedon indicates a date around 515 B.C. There are three open wounds on Sarpedon's body from which blood spills to the ground. His wound is not cleansed, although the Iliad relates the opposite ${ }^{75}$. The angle at which blood flows from his wounds indicates that the body is being moved to the right. He resembles the contemporary statues of kouroi, depicted as a long-haired and beardless aristocratic youth.

Euphronios introduces a new figure to us; the god Hermes, unmentioned in Homer's Iliad. In the center of the painting, Hermes, messenger god and conductor of souls, is seen as helpful. He is the helper of the most famous heroes such as Sarpedon, leading the souls of the dead to the underworld. Hermes is shown as directed and turned towards the right. He stands in profile to the left. He is bearded and with long hair which is smooth at the back and represented in horizontal rolls in the front. In early Greek art, Hermes is depicted as a mature bearded man. He wears a chiton, winged sandals and conducts this corpse using hand directives. Hermes is famous as the

${ }^{75}$ Hom. Il. XVI, 670 ff. "conductor" of people with souls and we see him as a mediator between the living and the dead. In fact, on the vase by Euphronios, Hermes conducts the hero's body back to Lycia, holding a caduceus in his left hand ${ }^{76}$. The cadeceus carried by deities was a sign of their power and ability to move between realms.

A scene of armed youths decorates the reverse side of the vessel and all of the major figures in this scene are identified by inscriptions. Standing behind Hypnos and Thanatos are Laodamas and Hippolochos, two Trojan warriors killed in the battle prior to Sarpedon (Fig. 14 b). The younger warriors are both armed and clothed, in contrast to the dead hero who is weaponless and completely naked. Their ages are distinguished by head type and body style. They are shown in fighting apparatus like shield and spears carrying a shield suspended from their left shoulders, and holding a spear in their right hands. Their hair falls to their shoulders. The same motif is known from Attic gravestones of the Classical period. Painters and sculptors, generally, share the same repertoire. In this period, Attic painters experimented with ways of depicting bodies.

In conclusion, from ancient times to the present, the phenomenon of hero has been commonly studied and variously defined. The Greek hero cult in particular has been extensively discussed by both archaeologists and philologists. Works of ancient writers like Euripides, Plutarchos and Apollodorus are important documentary sources in connection with the hero and heroine cult. Homer has described powerful generations of men, honored heroes and the importance of their tombs in

\footnotetext{
${ }^{76}$ Hermes, messenger of the gods and psychopompus (conductor of souls to the underworld). $\mathrm{He}$ is recognized by the caduceus, his wide- brimmed hat, cloak, and winged sandals.
} 
his poems. For example, Lycians and Lycian heroes, who fought on the side of the Trojans in defence of Troy, are mentioned in Homer's Iliad, the most famous of whom is Sarpedon ${ }^{77}$. Different descriptions of Sarpedon can be found on ceramics. The most famous is the crater painted by Euphronios in the late sixth century B.C. It supports the episode of Sarpedon's death as mentioned in Homer's Iliad. The cult of Sarpedon was concentrated primarily along the western regions of Asia Minor's southern shore and it was worshipped. It is clear that Sarpedon, a hero of Asia Minor is connected with Lycia. Although there is no detailed information on this subject, Xanthos, which is one of the most important cities in Lycia, as mentioned in ancient sources, must be the cult center of Sarpedon.

\section{ILLUSTRATIONS LIST}

Figure 1: Hector and Achilles are fought on a Corinthian cylix. Sarpedon is behind of Hector and similarly Phoenix flanks by Achilles (LIMC 1981, VII/2, Taf. 519, Fig. 1).

Figure 2: Hypnos and Thanatos, both bearded and wearing armor, lift the lifeless body of Sarpedon from the battlefield or laid down in his homeland (LIMC 1981, VII/2, Pl. 523, Fig. 15.; Fabing 1988, $244-$ 249, No. 45).

Figure 3: Fight over the dead body of Sarpedon. He's body is seen under the war vehicles (LIMC 1981, VII/2, Pl. 520, Fig. 2).

Figure 4: While Hypnos and Thanatos are carrying the body of Sarpedon, Akamas, Trojan hero, is leading them (LIMC 1981, VII/2, Pl. 520, Fig. 3).

Figure 5: Hypnos and Thanatos are laying down the body of Sarpedon. The other

\footnotetext{
${ }^{77}$ Hack 1929, 57 ff; Hadzisteliou 1973, 129 ff.
}

figures can be defined as goddesses Iris (on the left) and Sarpedon's mother or wife (on the right) (LIMC 1981, VII/2, Pl. 521, Fig. 5; Robertson 1992, 39-40, Fig. 21).

Figure 6: Hypnos and Thanatos, two winged daemons, carry the body of Sarpedon off the ground. An eidolon, unarmed, flies downward above the group (LIMC 1981, VII/2, Pl. 521, Fig. 6).

Figure 7: Hypnos and Thanatos deposit the body of Sarpedon; an eidolon, fully armed, flies downward

(Haspels 1936, 238, 133; LIMC 1981, VII/2, P1. 521, Fig. 7).

Figure 8: Hypnos and Thanatos lift the dead body of Sarpedon from the battlefield or lay down in his home, an eidolon flies upward (Haspels 1936, 239, 137; LIMC 1981, VII/2, Pl. 521, Fig. 8).

Figure 9: Sarpedon is lifted by Hypnos and Thanatos from the battlefield after his death (Boardman 1995 b, Fig. 251).

Figure 10 a: Sarpedon who lost his armour, is lifted by Hypnos and Thanatos. The god Poseidon holding a dolphin in the left hand (LIMC 1981, VII/2, Pl. 522, Fig. 10)

Figure 10 b: Sarpedon is lifted by Hypnos and Thanatos. The god Hermes in front of the warrior stand (LIMC 1981, VII/2, Pl. 522, Fig. 10)

Figure 11: The two fragments from the outside of a cylix, only a small part of the legs and foots of a male figure. The body of Sarpedon is removed by Hypnos and Thanatos from the battlefield or is laid down in his home (LIMC 1981, VII/2, Pl. 522, Fig. 11)

Figure 12: Sarpedon's body is carried by Hypnos and Thanatos. Mortal Europa, mother of Sarpedon, enthroned in a stage aedicula, by her side on the lower level a woman (perhaps the wife of Sarpedon) sits (LIMC 1981, VII/2, Pl. 522, Fig. 14)

Figure 13: Hypnos and Thanatos aloft the body of Sarpedon, whose name is incised on. Below them, is shown Achilles, full 
armed, killing Penthesilea (LIMC 1981, VII/2, P1. 522, Fig. 13)

Figure 14 a: Hypnos and Thanatos lift the body of Sarpedon supervised end directed by Hermes, whose names are incised on (LIMC 1981, VII/2, Pl. 520, Fig. 4; Boardman 1996, Fig. 22)

Figure 14 b: The back of crater, showing a group warriors. Standing behind Hypnos and Thanatos are Laodamas and Hippolochos, two Trojan warriors who are killed in battle prior to Sarpedon (LIMC 1981, VII/2, Pl. 520, Fig. 4)

\section{Yrd.Doç.Dr.Aslı Saraçoğlu}

Adnan Menderes Üniversitesi

Fen-Edebiyat Fakültesi

Arkeoloji Bölümü

Kepez / AYDIN

aslisaracoglu@hotmail.com

\section{REFERENCES}

Ainian 1997

Ainian 1999

Antonaccio 1994

Antonaccio 1995

Benton 1938/39

Blegen 1937

Boardman 1995a

Boardman 1995b

Boardman 1996
A. M. Ainian, From Rulers' Dwellings to Temples: Architecture, Religion and Society in Early Iron Age Greece (1100-700 BC) (SIMA 121), Jonsered (1997).

A. M. Ainian, "Reflections on Hero Cults in Early Iron Age Greece", (ed R. Hägg) Ancient Greek Hero Cult. Proceedings of the Fifth International Seminar on Ancient Greek Cult, 21-23 April 1995, Stockholm (1999) 9-36.

C. M. Antonaccio, "Contesting the Past: Tomb Cult, Hero Cult, and Epic in Early Greece", AJA 98 (1994) 389-410.

C. M. Antonaccio, An Archaeology of Ancestors: Tomb Cult and Hero Cult in Early Greece. Lanham (1995).

S. Benton, "The Date of Cretan Shields" BSA 39 (1938/39) 52-64.

C. Blegen, "Post Mycenaean Deposits in Chamber Tombs," ArchEph: 100 (1937) I, 377-390.

J Boardman, Greek Sculpture, The Late Classical Period, London (1995).

J. Boardman, Athenian Black Figure Vases, London (1995).

J. Boardman, Athenian Red Figure Vases, The Archaic Period, London (1996). 
Bothmer 1981

Broneer 1942

Carter 1989

Clark - Coulson 1978

Coldstream 1976

Fabing 1988

Förtsch 1995

Hack 1929

Hadzisteliou 1973

Hall 1999

Haspels 1936

Hild 1918

Hiller 1983

Humphreys 1980

Johansen 1951
D. von Bothmer, "The Death of Sarpedon", (ed. S.L. Hyatt), The Greek Vase, New York (1981) 63-80.

O. Broneer, "Hero Cults in the Corinthian Agora", Hesperia 11 (1942) 128-161.

J.B. Carter, "The Chests of Periander", AJA 93 (1989) 355-378.

M.E. Clark - W.D.E. Coulson, "Memnon and Sarpedon", Museum Helveticum 35 (1978) 65-73.

J. N. Coldstream "Hero-Cults in the Age of Homer"JHS 96 (1976) 8-18.

S. Fabing, The Gods Delight: The Human Figure in Classical Bronze, Cleveland (1988).

R. Förtsch, Zeugen der Vergangenheit: (eds. M. Wörrle-P. Zanker) Stadtbild und Bürgerbild im Hellenismus 47 (1995) 173-188.

R.K. Hack, "Homer and the Cult of Heroes" TAPA 60 (1929) 5774.

T.P. Hadzisteliou, "Hero Cult and Homer", Historia 22 (1973) 129-144.

J. M. Hall, "Beyond the Polis: the Multilocality of Heroes" (ed. R. Hägg), Ancient Greek Hero Cult. Proceedings of the Fifth International Seminar on Ancient Greek Cult, 21-23 April 1995, Stockholm (1999) 49-59.

E. Haspels, Black-Figured Lekythoi, Paris (1936).

J. A. Hild, "Herois" in Dictionnaire des antiquités grecques et romaines, (eds. C. Daremberg and E. Saglio). Vol. 3. Paris (1918).

S. Hiller, "Possible Historical Reasons for the Rediscovery of the Mycenaean Past in the Age of Homer", (ed. R. Hägg), The Greek Renaissance of the Eight Century B.C... Tradition and Innovation. Second International Symposium at the Swedish Institute at Athens in 1981, Stockholm (1983) 9-15.

S.C. Humphreys, "Family Tombs and Tomb Cult in Ancient Athens", Tradition or Traditionalism?" Jhs.100 (1980) 96-186.

K. F. Johansen, The Attic Grave-Reliefs of the Classical Period, 
Copenhagen (1951).

Lambrinoudakis $1988 \quad$ V. G. Lambrinoudakis, "Veneration of Ancestors in Geometric Naxos," (eds. R. Hägg-N. Marinatos-G.C. Nordquist) Early Greek Cult Practice (1988) 235-245.

LIMC 1981

Lyons 1997

Mylonas 1948

Nagy 1983

Nagy 1990

Nock 1944

Norris 2000

Pipili 1987

Robertson 1988

Robertson 1992

Schefold 1964
Lexicon Iconographicum Mythologiae Classicae, Zurich and München (1981).

D. Lyons, Gender and Immortality, Heroines in Ancient Greek Myth and Cult, Princeton (1997).

G. Mylonas, "Homeric and Mycenaean Burial Customs", AJA 52 (1948) 56-81.

G. Nagy, "On the Death of Sarpedon" in Approaches to Homer, (eds. C.A. Rubino-C.W. Shelmerdine), Austin (1983) 189-217.

G. Nagy, Greek Mythology and Poetics, Ithaca (1990).

A.D. Nock, "The Cult of Heroes" HThr 37 (1944) 141-174.

M. Norris, Greek Art, from Prehistoric to Classical a Resource for Educators The Metropolitan Museum of Art, New York (2000).

M. Pipili, Laconian Iconography of the Sixth Century B.C, Oxford (1987).

M. Robertson, "Sarpedon Brought Home", (eds. J.H. Betts, J.T. Hooker, J.R. Green) Studies in Honor of TBL Webster, Vol. 2, Bristol (1988) 109-120.

M. Robertson, The Art of Vase-Painting in Classical Athens, Cambridge (1992).

K. Schefold, Frühgriechische Sagenbilder, München (1964). 


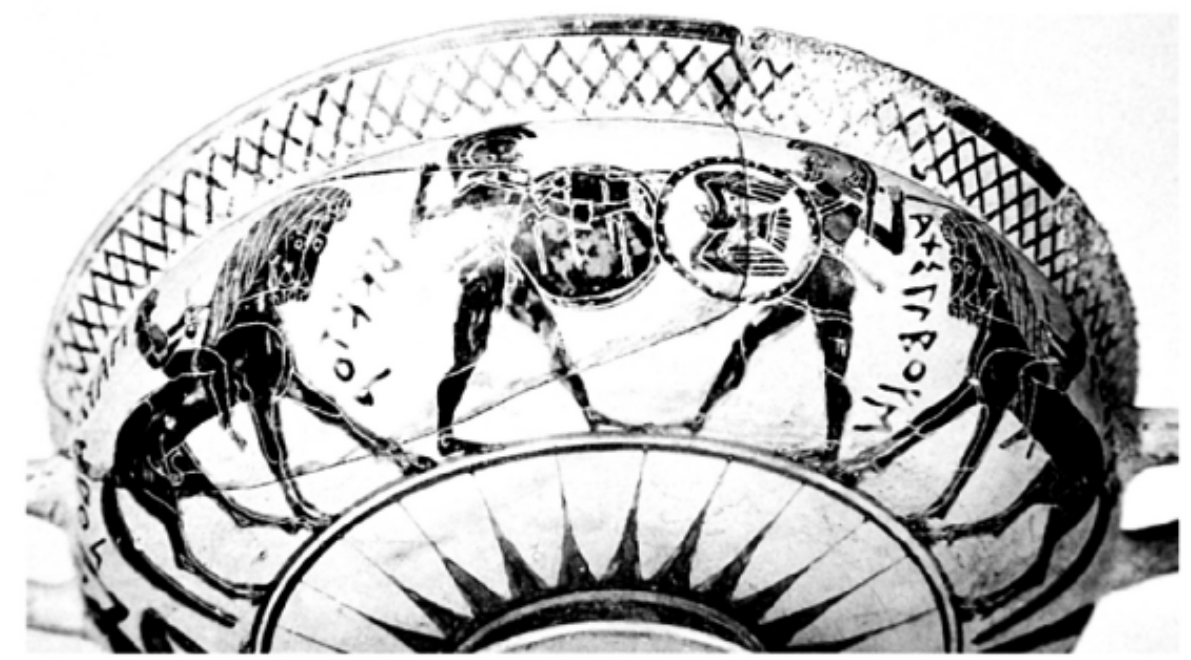

Figure 1: Hector and Achilles are fought on a Corinthian cylix. Sarpedon is behind of Hector and similarly Phoenix flanks by Achilles (LIMC 1981, VII/2, Taf. 519, Fig.1).

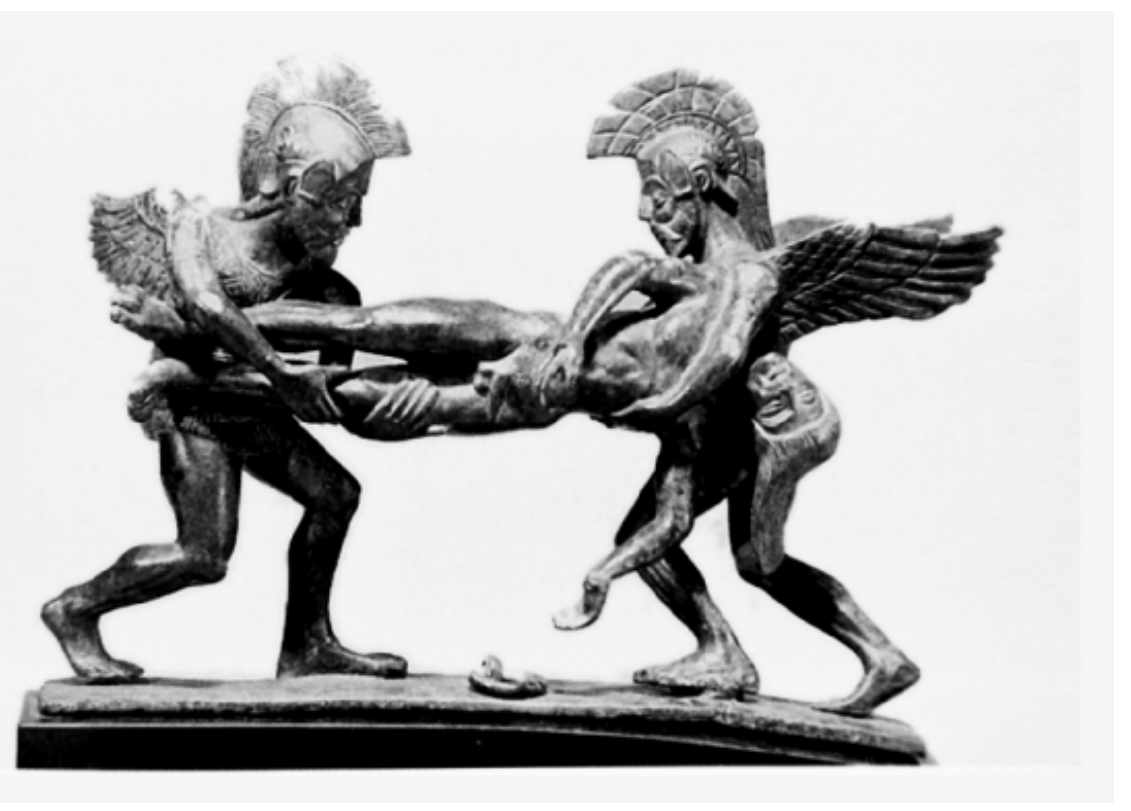

Figure 2: Hypnos and Thanatos, both bearded and wearing armor, lift the lifeless body of Sarpedon from the battlefield or laid down in his homeland (LIMC 1981, VII/2, P1. 523, Fig. 15; Fabing 1988, 244-249, No. 45). 


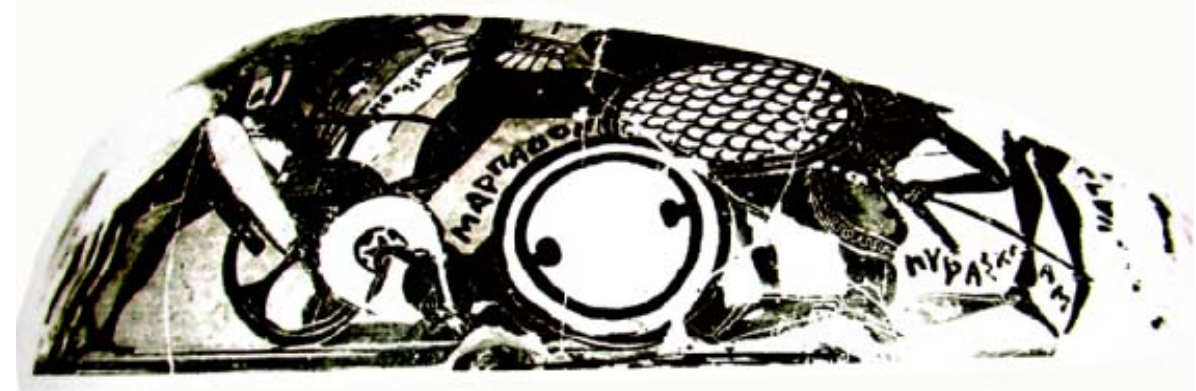

Figure 3: Fight over the dead body of Sarpedon. He's body is seen under the war vehicles (LIMC 1981, VII/2, Pl. 520, Fig. 2).

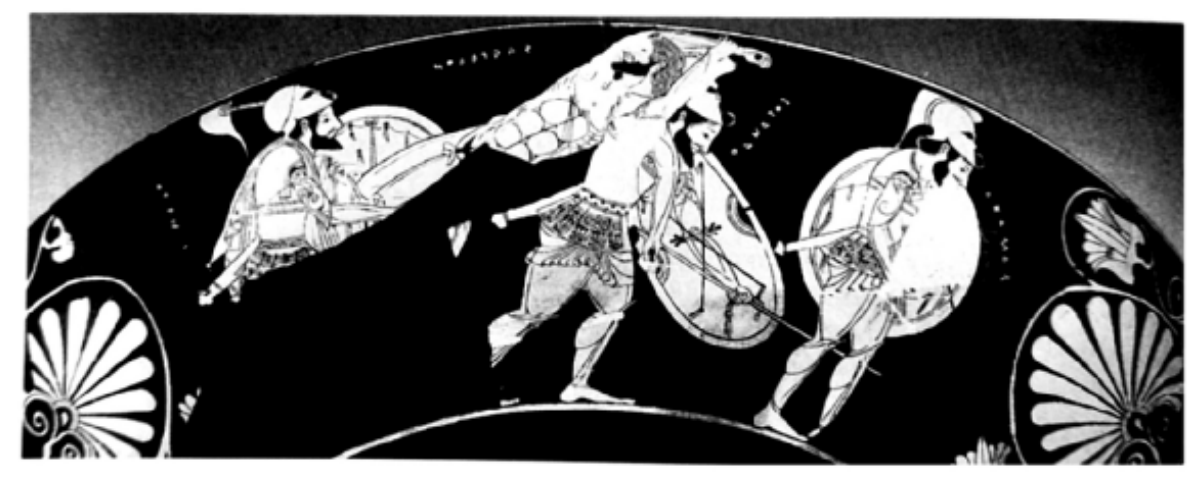

Figure 4: While Hypnos and Thanatos are carrying the body of sarpedon, Akamas, Trojan hero, is leading them (LIMC 1981, VII/2, Pl. 520, Fig. 3). 


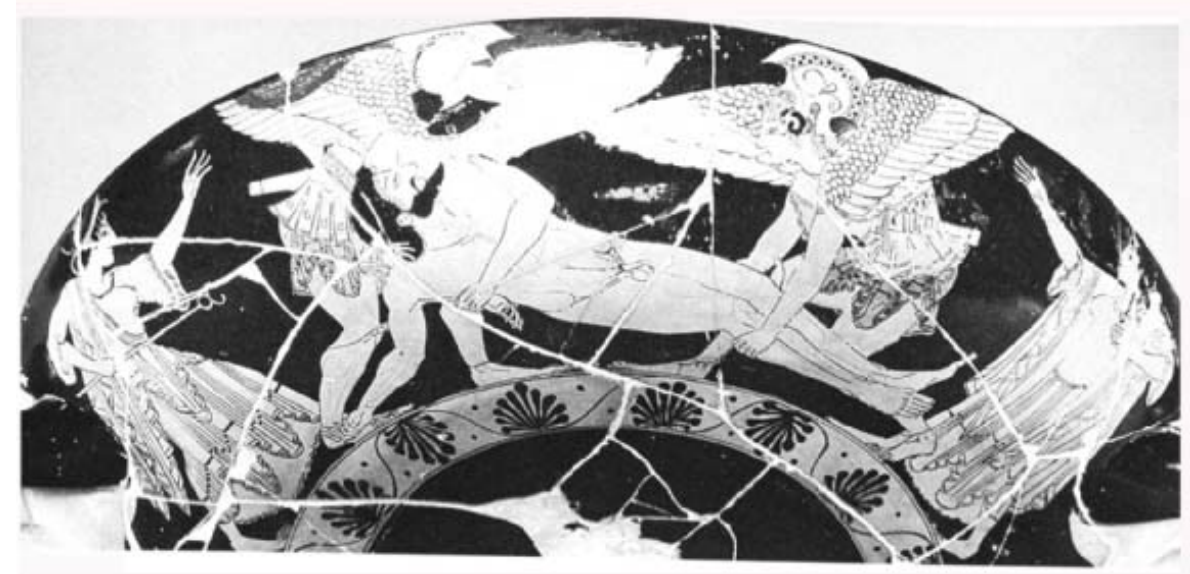

Figure 5: Hypnos and Thanatos are laying down the body of Sarpedon. The other figures can be defined as goddesses Iris (on the left) and Sarpedon's mother or wife (on the right) (LIMC 1981, VII/2 P1. 521, Fig. 5; Robertson 1992, 39-40, Fig. 21).

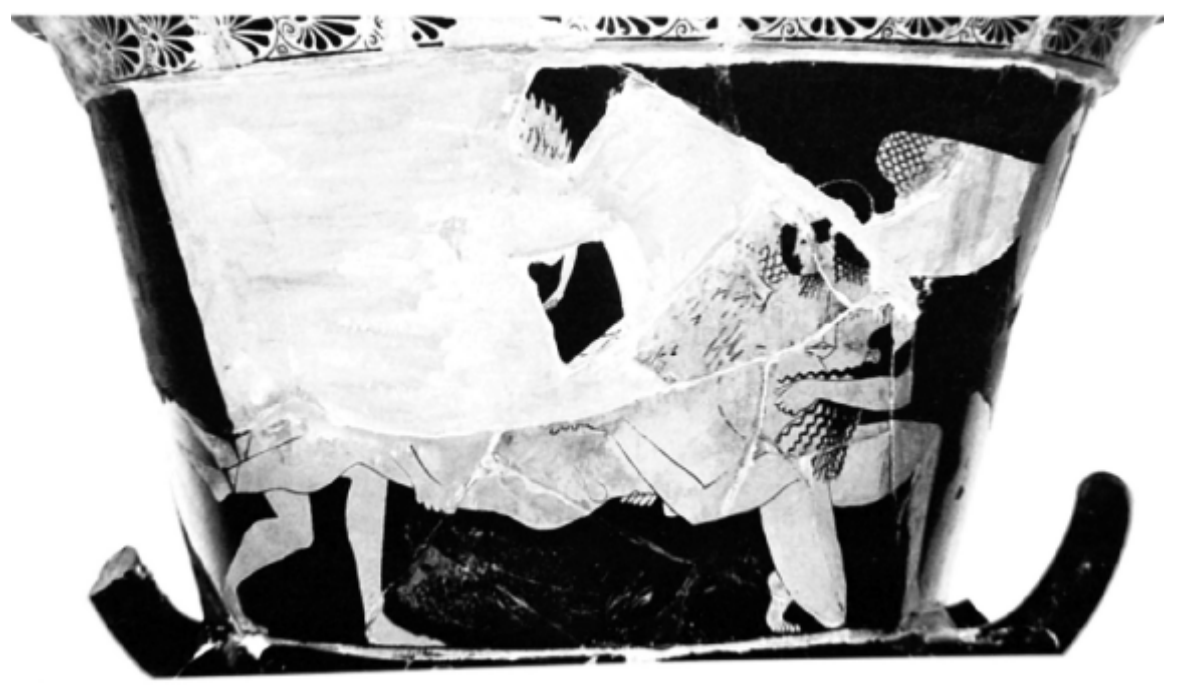

Figure 6: Hypnos and Thanatos, two winged daemons, carry the body of Sarpedon off the ground. An eidolon unarmed, flies downward above the group (LIMC 1981, VII/2, Pl. 521, Fig. 6). 


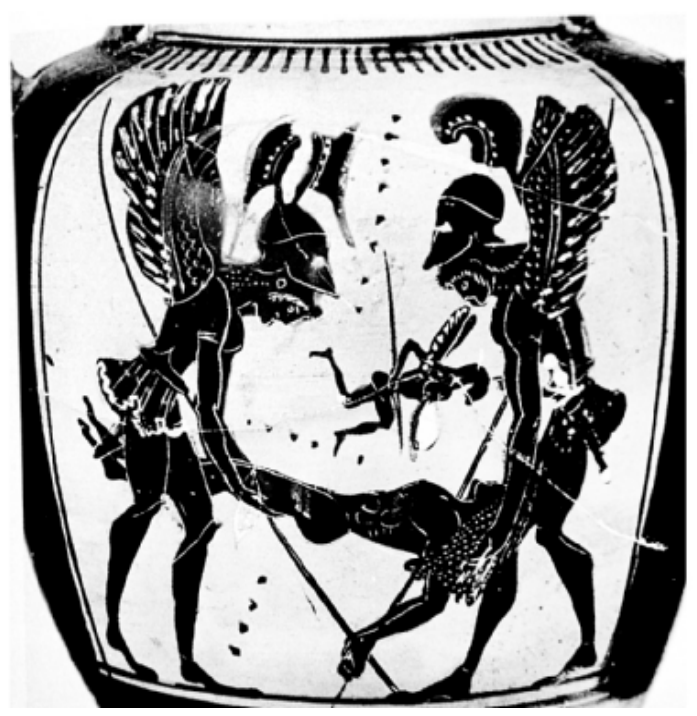

Figure 7: Hypnos and Thanatos deposit the body of Sarpedon; an eidolon, fully armed, flies downward (Haspels 1936, 238, 133; LIMC 1981, VII/2, Pl. 521, Fig. 7).

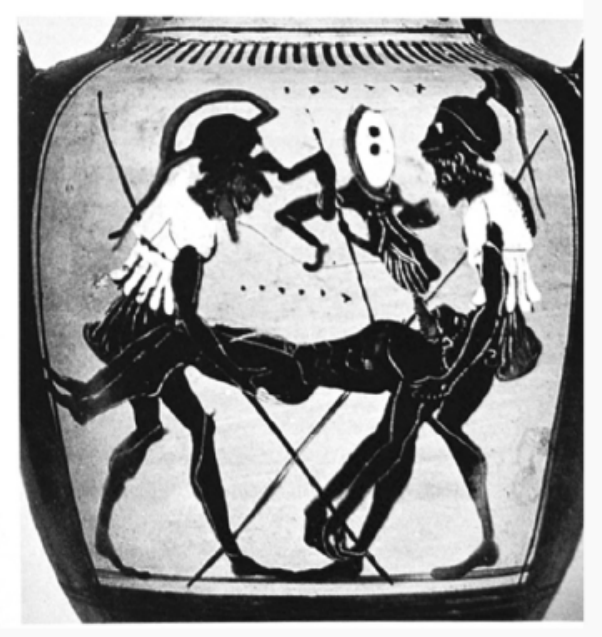

Figure 8: Hypnos and Thanatos lift the dead body of Sarpedon from the battlefield or lay down in his home, an eidolon flies upward (Haspels 1936, 239, 137; LIMC 1981, VII/2, P1. 521, Fig. 8). 


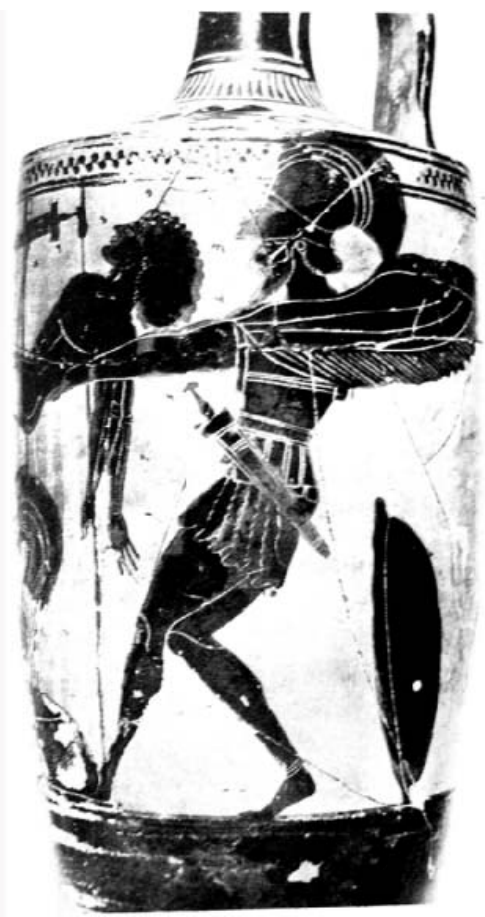

Figure 9: Sarpedon is lifted by Hypnos and Thatanos from the battlefield after his death (Boardman 1995b, Fig. 251).

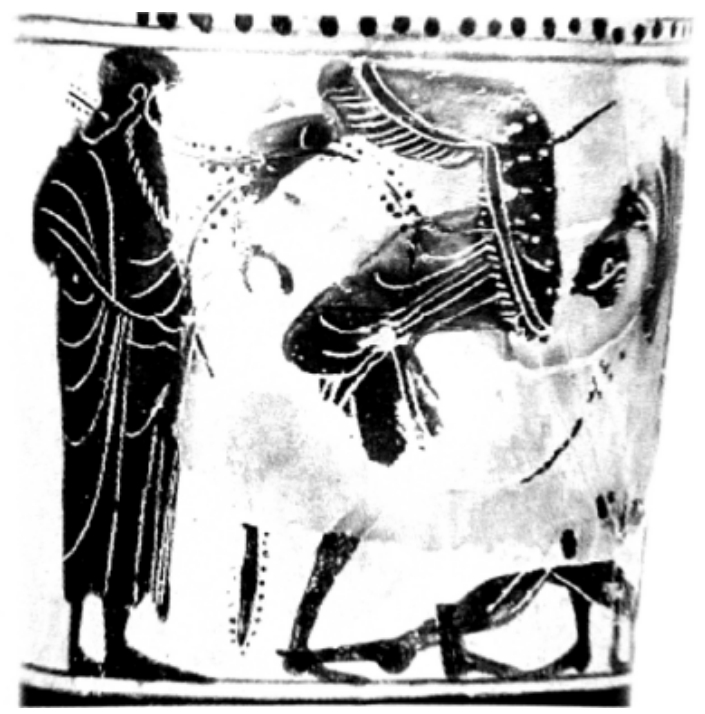

Figure 10 a: Sarpedon who lost his armour, is lifted by Hypnos and Thatanos. The god Poseidon holding a dolphin in the left hand (LIMC 1981, VII/2, Pl. 522, Fig. 10). 


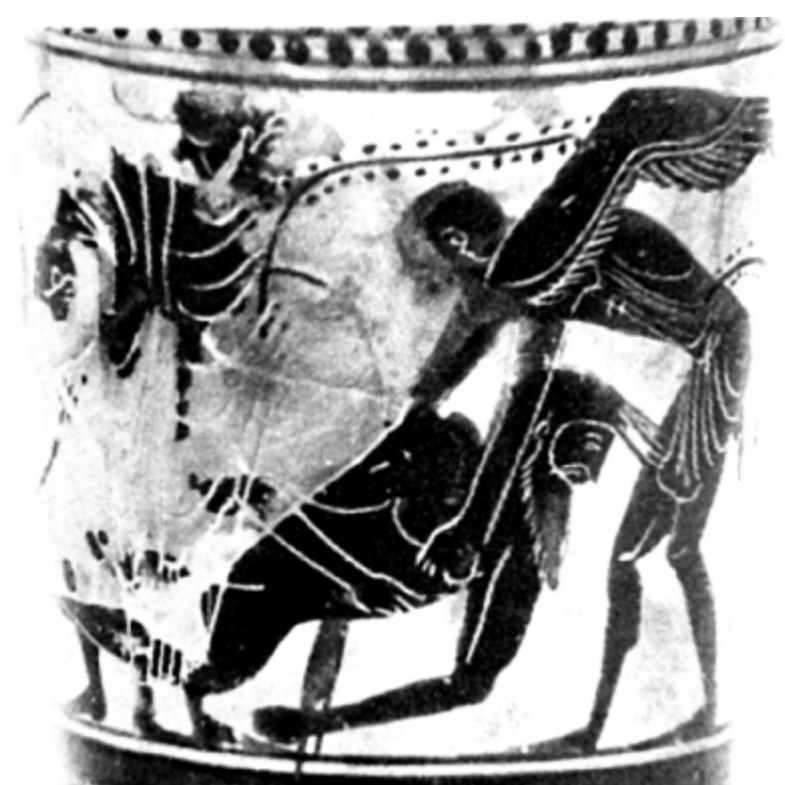

Figure $10 \mathrm{~b}$ : Sarpedon is lifted by Hypnos and Thanatos. The god Hermes in front of the warrior stand (LIMC 1981, VII/2, P1. 522, Fig. $10)$.

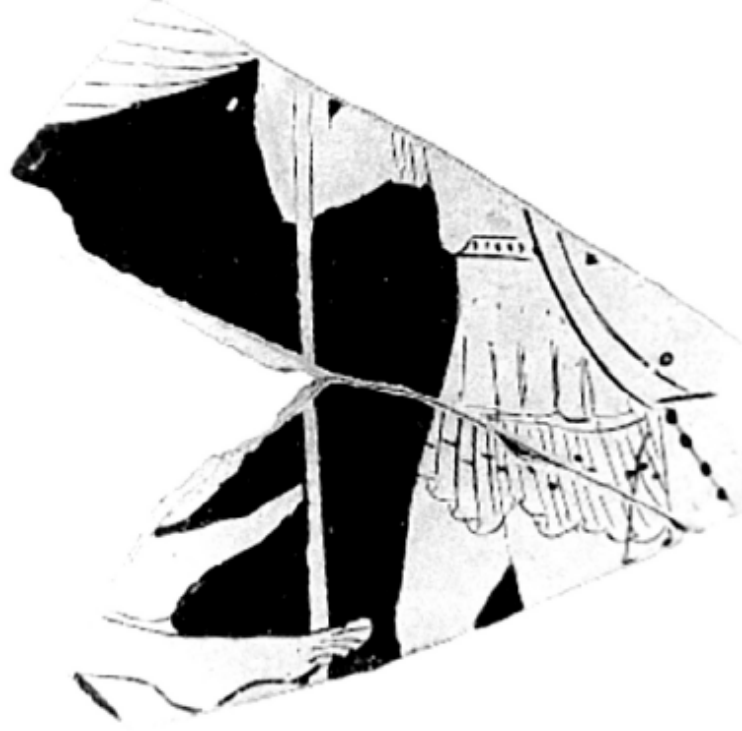

Figure 11: The two fragments from the outside of a cylix, only a small part of the legs and foots of a male figure. The body of Sarpedon is removed by Hypnos and Thanatos from the battlefield or is laid down in his home (LIMC 1981, VII/2, Pl. 522, Fig. 11). 


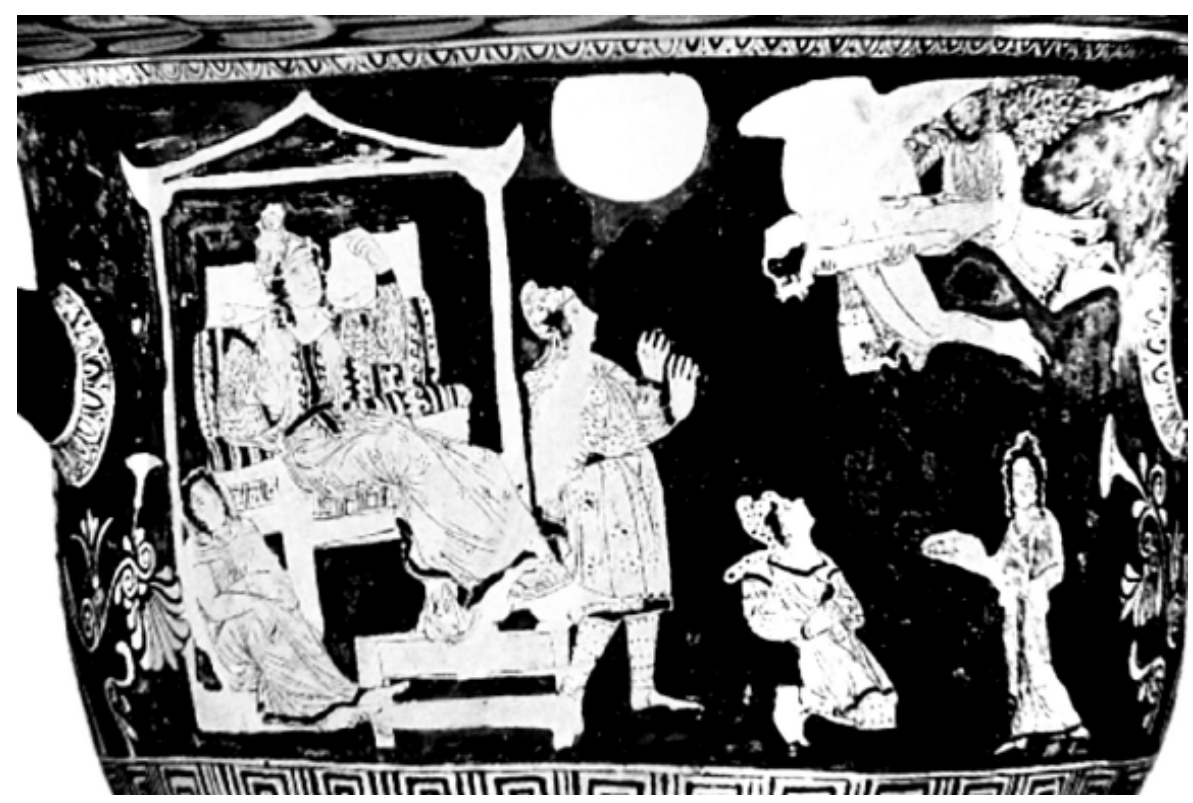

Figure 12: Sarpedon's body is carried by Hypnos and Thanatos . Mortal Europa, mother of Sarpedon, enthroned in a stageaedicula, by her side on the lower level a woman (perhaps the wife of Sarpedon) sits (LIMC 1981, VII/2, P1. 522, Fig. 14).

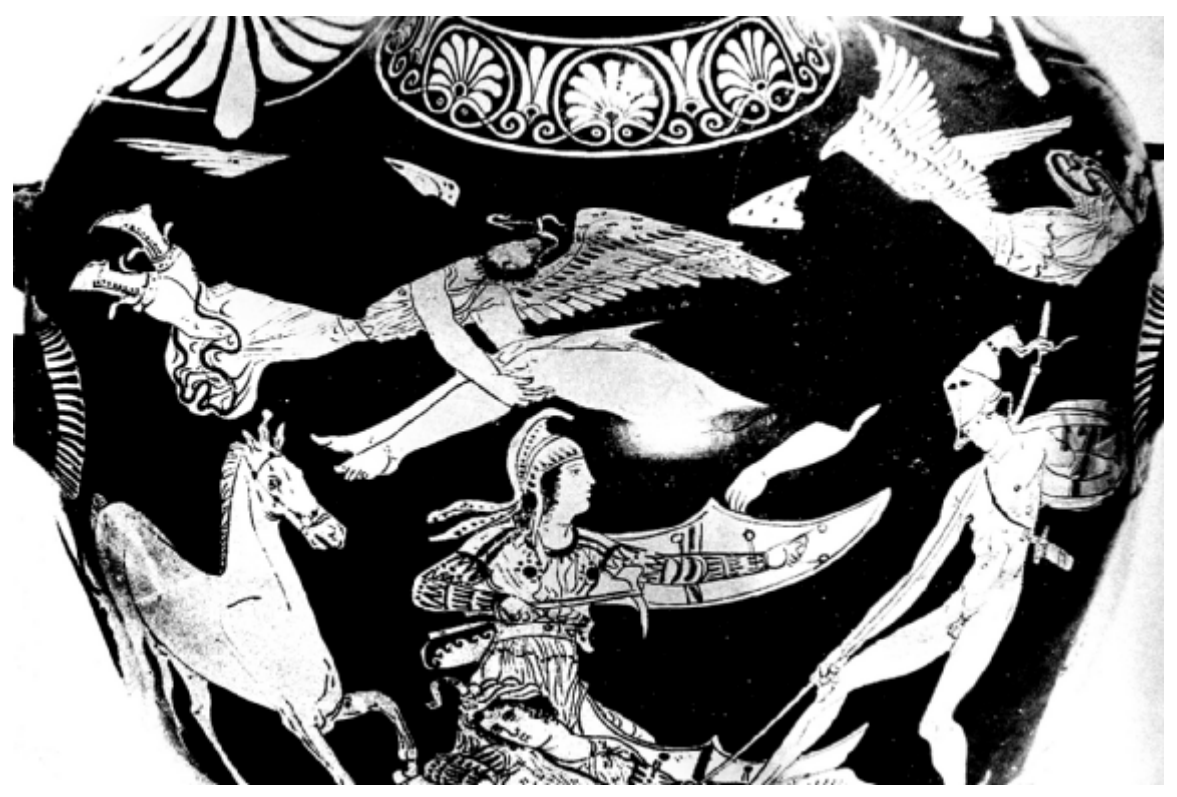

Figure 13: Hypnos and Thanatos aloft the body of Sarpedon, whose name is incised on. Below them, is shown Achilles, full armed, killing Penthesilea (LIMC 1981, VII/2, Pl. 522, Fig. 13). 


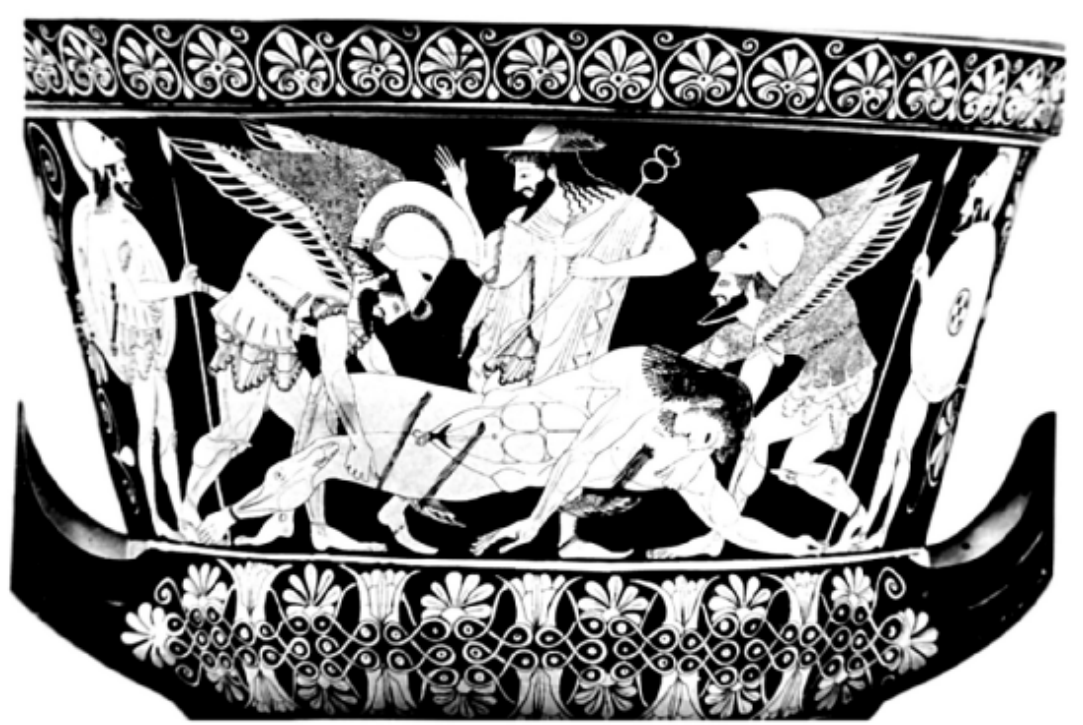

Figure 14 a: Hypnos and Thanatos lift the body of Sarpedon supervised end directed by Hermes, whose names are incised on (LIMC 1981, VII/2, Pl. 520, Fig. 4; Boardman 1996, Fig. 22).

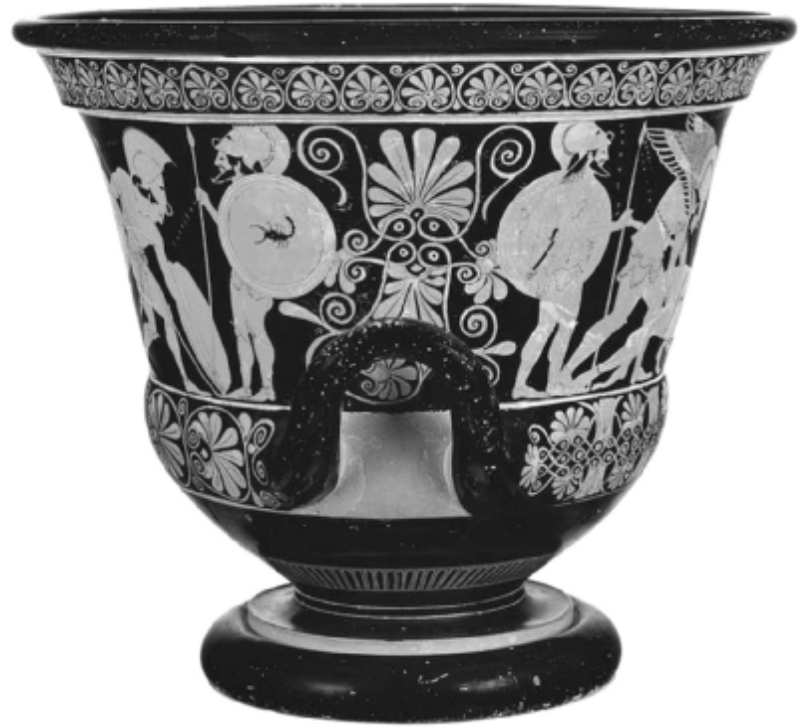

Figure $14 \mathrm{~b}$ : The back of crater, showing a group warriors. Standing behind Hypnos and Thanatos are Laodamas and Hippolochos, two Trojan warriors who are killed in battle prior to Sarpedon (LIMC 1981, VII/2, Pl. 520, Fig. 4). 